\title{
Bioaccumulation of Heavy Metals, Even in Low Quantities, is the Main Causative Agent of Male Human Infertility in D. I. Khan Division
}

\author{
Aamer Abbas ${ }^{1}$, Jabbar Khan ${ }^{1 *}$, Mir Abid Hassan², Asif Qayyum ${ }^{3}$ and Hamed Shafiq ${ }^{4}$ \\ ${ }^{1}$ Department of Biological Sciences, Gomal University, Dera Ismail Khan, Khyber \\ Pakhtunkhwa, Pakistan \\ ${ }^{2}$ Kidney Centre Hayatabad, Peshawar, Khyber Pakhtunkhwa \\ ${ }^{3}$ Department of Electronics, Gomal University, Dera Ismail Khan \\ ${ }^{4}$ Cream Lab, Army Medical College, Rawalpindi, Pakistan
}

\begin{abstract}
A B S T R A C T
Metals can adversely affect the size of testis, the normal process of spermatogenesis and quality of semen. Moreover, metals can lead to decreased or no production of prostaglandin, seminal fluid and endocrinology of reproductive process and thus results in male infertility. It was also here attempted to characterize the drastic effects of heavy metals on male infertility, the hormone analysis and genetic determination of $S R Y$ gene as some of infertile human had smaller sized testis. Blood and semen samples were collected from clinically diagnosed 130 oligozoospermic males throughout D. I. Khan. The patients included had been married for 3 to 19 years, their wives had normal reproductive capabilities; the couples were living together for more than 3 years but fertilization had not occurred. Separation of sperm samples from semen plasma, sperm counting and DNA extraction for assessment of clinical and molecular attributes was done using standard protocols. Healthy women were used as negative controls. This study revealed significant concentrations of $\mathrm{Zn}, \mathrm{Cd}, \mathrm{Cr}, \mathrm{Pb}, \mathrm{Cu}$. Except $\mathrm{Zn}$ and $\mathrm{Pb}$, the other 3 metals were found below the permissible limit set by WHO. Interestingly, the infertile males having maximum age limit of above 47 years and highest marriage ages during the present study showed comparatively higher concentrations of all the heavy metals. Zinc was found with highest means values while cadmium was recorded with lowest concentrations. On comparing severe oligozoospermia with mild/moderate oligozoospermic patients with respect to semen analysis, it was observed that head, mid-piece and tail defects were comparatively much higher in severe oligozoospermic individuals than mild/moderate individuals. Similarly, the movement of sperms, either lateral or forward movement was observed much lesser in severe forms of oligozoospermia than mild/moderate oligozoospermia. The same observed for the total number of sperms as the sperm counts were comparatively much smaller in severe oligozoospermic than mild/moderate oligozoospermic individuals. No mutation/deletion was found, neither in oligozoospermic individuals nor in normal males in SRY gene, located on Y chromosome. Hence, the presence of heavy metals, even in small quantities in the bodies of oligozoospermia males can be one of the main causative agents of male infertility.
\end{abstract}

\author{
Article Information \\ Received 29 April 2020 \\ Revised 19 November 2020 \\ Accepted 10 December 2020 \\ Available online 09 September 2021 \\ Authors' Contribution \\ AA collection of samples, experimental \\ work. JK designing research work, \\ manuscript writing. MAH clinical \\ investigation and hormone analysis. \\ AQ statistical analysis. HS financial \\ support and sample collection. \\ Key words \\ Infertility, Heavy metals, Semen \\ analysis, SRY gene, Oligozoospermia
}

\section{INTRODUCTION}

$\mathrm{T}$ he inability of a man to conceive after one year of unprotected intercourse can be called as having subfertility. Proposed causes of infertility in men include varicocele, obstruction of the spermatic ducts, agglutination of sperm, high semen viscosity, necrospermia, low volume of ejaculate, ejaculatory dysfunction, and high sperm density. Heavy metals are also known for their toxic effects on living things including human by impairing enzymes activities and production of free radicals. Since human body does not need them and is not a part of daily diet,

\footnotetext{
Corresponding author: sjabbarkhan@yahoo.com 0030-9923/2021/0006-2049 \$ 9.00/0

Copyright 2021 Zoological Society of Pakistan
}

consumption of food is one of the major sources of exposure to these heavy metals globally (CDC, Atlanta, 2003, 2005). Metals can equally disturb both male and female reproductive systems by inducing the generation of reactive oxygen species (Nordberg et al., 2007; Symposium Proceedings, 1992). Infertility thus has affected more than $15 \%$ of those couples who wish to have children like them and, more than $50 \%$ of such cases are because of male human infertility (Adachi et al., 1992; Mosher, 1985). Metals can adversely affect the size of testis, the normal process of spermatogenesis and quality of semen. Moreover, metals can lead to decreased or no production of prostaglandin, seminal fluid and endocrinology of reproductive process and thus results in male infertility (Benoff et al., 2000; Wirth and Mijal, 2010; Apostoli and Catalani, 2011). The well-known causes leading male 
human infertility are blockage of ejaculatory duct, low volume of semen, lysis of spermatids, agglutination of spermatozoa, and impairment in ejaculatory process. Form molecular point of view, deletions and point mutations in certain chromosomes are the major causes of male human infertility. The notable of molecular abnormalities are microdeletions of $\mathrm{Y}$ chromosome and specific deletion or point mutations of $\mathrm{Y}$ chromosomal genes. The azoospermia factor on $\mathrm{Y}$ chromosome is regarded as one of the most pathogenic factors, leading to male infertility of varying degree and is the most intensively characterized region in this regard. Additionally, KLHL10 (Wang et al., 2006) mutations, responsible for oligozoospermia, abnormalities in SPATA16 (Karaca et al., 2014) induces globozoospermia, a frameshift mutation in aurora kinase C genes (Dale et al., 1994) is responsible for large headed polyploid spermatozoa or macrozoospermia, HSF2, belonging to the family of heat-shock transcription factor and plays a key role in regulating normal spermatogenesis, induces idiopathic azoospermia in humans when mutated (Mou et al., 2013). In the same way, SEPT12 (Kuo et al., 2012), TAF4B (Freiman et al., 2001) and ZMYND15 (Falender et al., 2001) lead to varying degree of infertility in their mutated forms. Keeping in view the widespread exposure of humans and known toxic effects of the metals, an attempt was made during this study to explore the means concentration of heavy metals both in the blood and semen samples of male infertile individuals of inhabitants of D.I. Khan district. The main focus was to characterize the drastic effects of heavy metals on male infertility, even at low concentration and genetic determination of $S R Y$ gene as some of infertile human had smaller sized testis.

\section{MATERIALS AND METHODS}

\section{Sample collection, preparation and DNA extraction}

Blood and semen samples were collected from clinically diagnosed 120 oligozoospermic males throughout D. I. Khan and analyzed for the detection of heavy metals and biochemically characterized for their hormonal profile. Moreover, the patients were molecular assessed for the possible role of $S R Y$ gene as $10 \%$ of the patients had small size testis for more than 8 years. The patients included had been married for 3 to 19 years, their wives had normal reproductive capabilities; the couples were living together for more than 3 years but fertilization had not occurred. Separation of sperm samples from semen plasma for assessment of clinical attributes was done through centrifugation for $15 \mathrm{~min}$ at $1600 \mathrm{~g}$ (Abdulali et al., 2003) after washing three times with an equal volume of M6 solution (per liter, $\mathrm{pH}=7.5$ ): $0.50 \% \mathrm{NaCl}, 0.04 \%$ $\mathrm{KCl}, 0.020 \% \mathrm{CaCl} 2,0.015 \% \mathrm{~K}_{3} \mathrm{PO}_{4}, 0.030 \% \mathrm{MgSO}_{4}$,
$0.035 \% \mathrm{NaHCO}_{3}, 0.50 \%$ HEPES, $0.25 \%$ sodium lactate, $35 \times 10-4 \%$ sodium pyruvate, $0.12 \%$ glucose, $0.45 \%$ bovine serum albumin, $55 \times 10-4 \%$ penicillin, and $50 \times 10-$ $4 \%$ streptomycin. Sperms were counted using MMC-SK Sperm Counting Chamber (Saint Petersburg, Russia). The study, conducted during September 2017 to May 2019, was approved by Gomal University Ethical Board and written consent of both the patients and of the normal individuals was obtained. For extraction of DNA, $2 \mathrm{ml}$ venous blood from each individual was drawn and put in an anticoagulation tube. DNA was extracted by salting-out method (Miller et al., 1988). The concentration and purity of DNA were detected using NanoDrop spectrophotometer Thermo Scientific, UK) and stored at $-20^{\circ} \mathrm{C}$ for further analysis. Healthy women were used as negative controls and 20 married men with semen volume $\geq 3.0$, sperm concentration/ $\mathrm{ml} \geq 50 \times 106$, forward motility $\geq 60 \%$, and atypical forms $\leq 40 \%$ ) were used as healthy controls.

\section{Heavy metal analysis}

All samples were digested with mixture of $\mathrm{H}_{2} \mathrm{O}_{2}+\mathrm{HNO}_{3}$, mixed with 1: 3 ratios (Abdulali et al., 2003) at $120^{\circ} \mathrm{C}$ for 30 minutes and allowed to cool at room temperature. Each sample was prepared in duplicate and diluted to a total volume of $12 \mathrm{ml}$ with ultra-pure water and filtered with $0.45 \mu \mathrm{m}$ membrane filter for detection of possible heavy metals. Analytical grade reagents were used and all the working solutions were prepared by making dilutions of stack solutions of $\mathrm{mg} / \mathrm{ml}$ from Perkin Elmer. The filtered samples were characterized for the possible presence of $\mathrm{Cd}, \mathrm{Cr}, \mathrm{Pb}, \mathrm{Cu}$ and $\mathrm{Zn}$, using atomic absorption spectrophotometer. The concentrations of heavy metals were presented in $\mu \mathrm{g} / \mathrm{ml}$.

\section{Genetic determination}

The samples for SRY gene located on Y chromosome were sequenced by the direct Sanger method (Sanger et al., 1977).

\section{RESULTS}

The very important and serious issue of presence of heavymetals inblood and semen samples of oligozoospermic males of inhabitants of D.I. Khan district was addressed. This study revealed significant concentrations of $\mathrm{Zn}$, $\mathrm{Cd}, \mathrm{Cr}, \mathrm{Pb}, \mathrm{Cu}$. Interestingly, the infertile males having maximum age limit of above 47 years and highest marriage ages during the present study showed comparatively higher concentrations of all the heavy metals. Zinc was found with highest means values while cadmium was recorded with lowest concentrations (Table I). 
Table I. Mean concentration of each metal $(\mu \mathrm{g} / \mathrm{ml})$, both in blood and in semen samples, plus mean of mean concentration of all the detected 5 heavy metals in each age group

\begin{tabular}{lllllll}
\hline $\begin{array}{l}\text { Age } \\
\text { Group }\end{array}$ & $\begin{array}{l}\text { Type of } \\
\text { sample }\end{array}$ & $\mathbf{C d}$ & $\mathbf{C r}$ & $\mathbf{P b}$ & $\mathbf{C u}$ & $\mathbf{Z n}$ \\
\hline $\begin{array}{l}18-23 \\
(\mathrm{n}=20)\end{array}$ & Blood & 0.027 & 0.251 & 0.066 & 0.615 & 2.036 \\
$24-29$ & Semen & 0.039 & 0.265 & 0.028 & 0.484 & 2.913 \\
$(\mathrm{n}=20)$ & Blood & 0.055 & 0.437 & 0.077 & 0.523 & 2.483 \\
$30-35$ & Blood & 0.037 & 0.530 & 0.117 & 0.479 & 1.628 \\
$(\mathrm{n}=20)$ & Semen & 0.040 & 0.525 & 0.180 & 0.519 & 0.695 \\
$36-41$ & Blood & 0.033 & 0.214 & 0.145 & 0.506 & 0.301 \\
$(\mathrm{n}=20)$ & Semen & 0.047 & 0.264 & 0.110 & 0.495 & 0.143 \\
$42-47$ & Blood & 0.050 & 0.402 & 0.062 & 0.325 & 1.719 \\
$(\mathrm{n}=20)$ & Semen & 0.016 & 0.573 & 0.231 & 0.586 & 2.469 \\
$>47$ & Blood & 0.098 & 0.679 & 0.245 & 0.704 & 2.844 \\
$(\mathrm{n}=20)$ & Semen & 0.091 & 0.489 & 0.222 & 0.469 & 1.830 \\
$\begin{array}{l}\text { Control } \\
(\mathrm{n}=30)\end{array}$ & Blood & 0.011 & 0.112 & 0.017 & 0.142 & 0.124 \\
\hline
\end{tabular}

Samples analysis for heavy metals

On analyzing age-wise distribution of all heavy metals both in blood and semen samples, it was observed that all the five detected heavy metals were recorded in highest quantities in above- 47 years of age group, followed by and 18-23 years of age groups (mean concentration of 0.767 $\mu \mathrm{g} / \mathrm{ml}$ and $0.672 \mu \mathrm{g} / \mathrm{ml}$ respectively (Table I, Figs. 1, 2, 3). The smallest average-mean concentration of $0.225 \mu \mathrm{g} / \mathrm{ml}$ of all detected heavy metals were recorded in 36-41 years of age group (Fig. 3). On determining the quantitative measurements of each heavy metal in different age groups, it was found that $\mathrm{Cd}$ was recorded in highest quantities in the above- 47 years of age group, both in blood and semen samples (Table I, Figs. 1 and 2) while the smallest mean concentration of $0.027 \mu \mathrm{g} / \mathrm{ml}$ in blood samples and 0.016 $\mu \mathrm{g} / \mathrm{ml}$ in semen samples were observed in the age group 1823 years and $42-47$ years of age groups respectively (Table I, Figs. 1 and 2). Variations within the group, both in blood and semen were not significant and the same was observed among the age groups. Like $\mathrm{Cd}, \mathrm{Cr}$ was also recorded in highest quantities in the above- 47 years of age group with mean concentration of $0.68 \mu \mathrm{g} / \mathrm{ml}$ for blood samples, and in 42-47 years of age groups for semen samples with average mean value of $0.57 \mu \mathrm{g} / \mathrm{ml}$. The smallest mean concentrations of $0.21 \mu \mathrm{g} / \mathrm{ml}$ and $0.26 \mu \mathrm{g} / \mathrm{ml}$ were found in blood and semen samples respectively of 36-41 years of age groups (Table I, Figs. 1 and 2). Variations among the age groups of 18-23 and 24-29 were significant both in blood and semen samples while for the rest of age groups the variations were negligible. In the same way, $\mathrm{Pb}$ was observed in comparatively highest amounts in above-47 years of age group (means conc. of $0.24 \mu \mathrm{g} / \mathrm{ml}$ for blood and $0.22 \mu \mathrm{g} / \mathrm{ml}$ for semen samples), followed by 30-35 years (Table I, Figs. 1 and 2) and 36-41 years of age groups. The smallest mean values of $0.066 \mu \mathrm{g} / \mathrm{ml}$ and $0.028 \mu \mathrm{g} / \mathrm{ml}$ for blood and semen samples, respectively of $\mathrm{Pb}$ were recorded in 18-23 years of age group (Figs. 1 and $2)$. For $\mathrm{Cu}$, the highest mean concentration $(0.70 \mu \mathrm{g} / \mathrm{ml}$, Table I, Figs. 1 and 2) of the metal was found in blood samples of above-47 age group, followed by $0.615 \mu \mathrm{g} / \mathrm{ml}$ observed in 18-23 years of age group that was interesting. The lowest concentration of $0.32 \mu \mathrm{g} / \mathrm{ml}$ was observed in blood samples of the age group 42-47 years, and $0.46 \mu \mathrm{g} /$ $\mathrm{ml}$ in semen samples of above- 47 years. Variations between the quantitative measurements of the metal in blood and semen samples were significant (Table I). Regarding the mean concentration of $\mathrm{Zn}$ in blood samples, the highest concentration of $2.84 \mu \mathrm{g} / \mathrm{ml}$ was observed in above- 47 years of age group, followed by $42-47$ years of age group $(2.47 \mu \mathrm{g} / \mathrm{ml})$, while the smallest mean values, both in blood and semen samples $(0.30 \mu \mathrm{g} / \mathrm{ml}$ and $0.14 \mu \mathrm{g} / \mathrm{ml}$, respectively) were recorded in 36-41 years of age group (Table I, Figs. 1 and 3). In semen samples, the highest mean concentration was interestingly observed in 18-23 years of age group. Interestingly, the mean concentration of $\mathrm{Zn}$ in blood samples varied significantly from that of semen samples both in the same individual and among the members of the same age group (Table I).

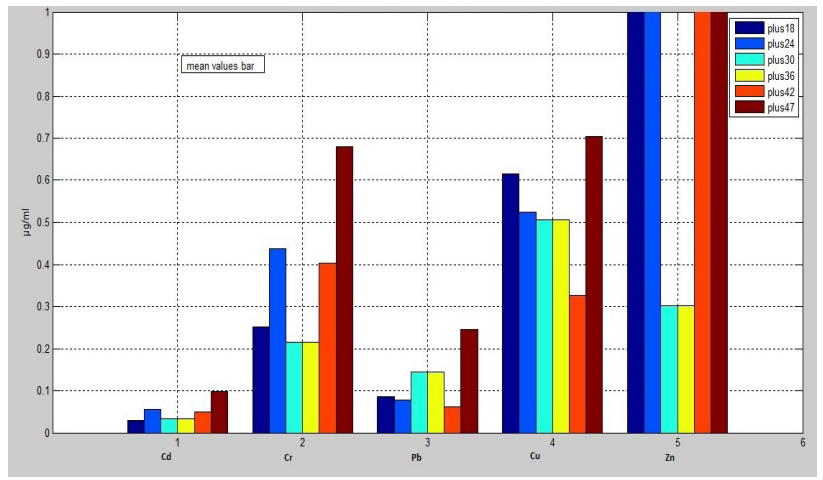

Fig. 1. Quantitative measurements of 5 detected metals in blood samples of oligozoospermic males of different age groups. Mean bar values of 1, 2, 3, 4 and 5 show mean concentration of $\mathrm{Cd}, \mathrm{Cr}, \mathrm{Pb}, \mathrm{Cu}$, and $\mathrm{Zn}$ respectively in age groups 18-23, 24-29, 30-35, 36-41, $42-47$ and above-47, Dark blue, Blue, Light blue, Yellow, Pink-red and Darkred bars are for $18-23,24-29,30-35,36-41,42-47$ and above- 47 years of age groups, respectively. 


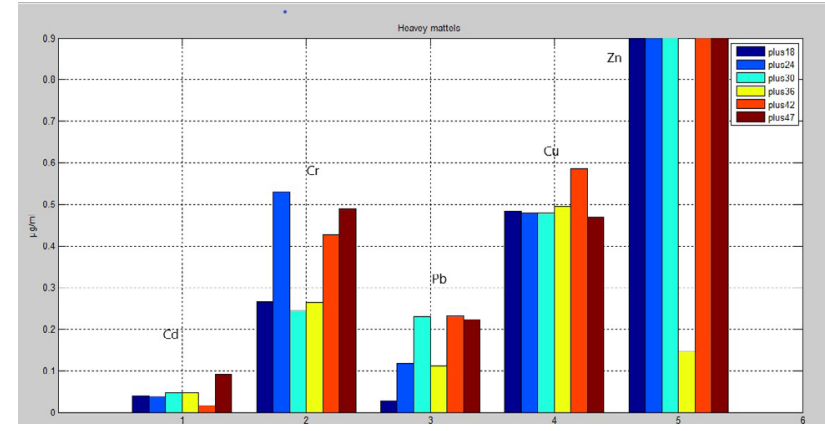

Fig. 2. Mean concentration in $\mu \mathrm{g} / \mathrm{ml}$ of 5 heavy metals in semen samples of oligozoospermia males of different age groups. Mean bar values of 1, 2, 3, 4 and 5 specify mean values of $\mathrm{Cd}, \mathrm{Cr}, \mathrm{Pb}, \mathrm{Cu}$ and $\mathrm{Zn}$ respectively in age groups 18-23, 24-29, 30-35, 36-41, 42-47 and above-47, Dark blue, Blue, Light-blue, Yellow, Pink-red and Dark-red bars are for $18-23,24-29,30-35,36-41,42-47$ and above-47 years of age groups, respectively.
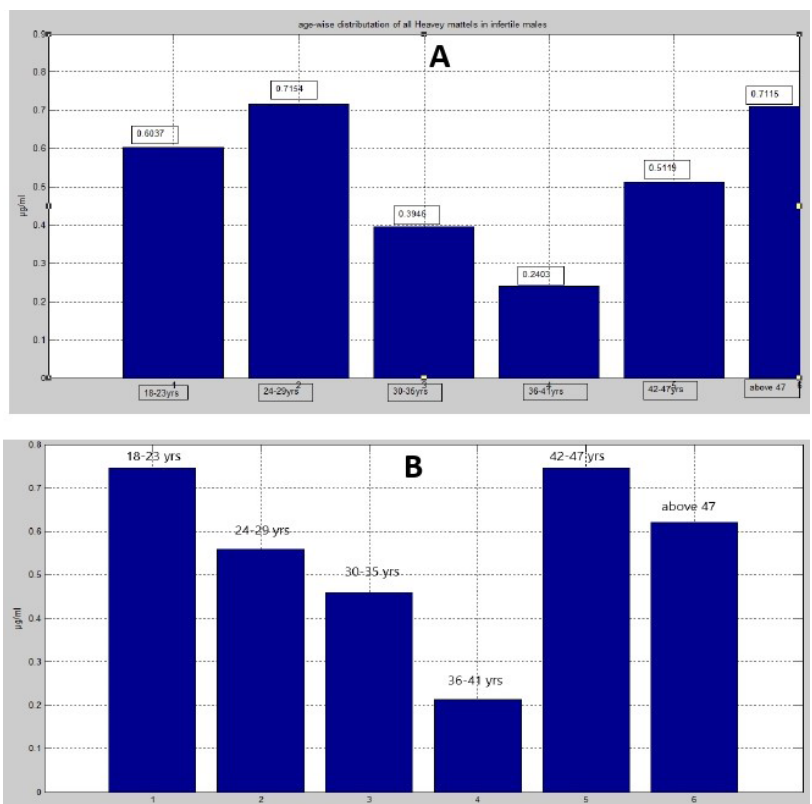

Fig. 3. A, Quantitative mean concentration of all 5 detected heavy metals in blood samples in each age group. As indicated above each bar is the mean concentration of heavy metals and below each bar is the age group. B, Quantitative mean values of all 5 detected heavy metals in semen samples in each age group. As mentioned above each bar is the mean value of heavy metals and age group is indicated below each bar.

\section{Semen analysis for sperm morphology}

On comparing severe oligozoospermia with mild/ moderate oligozoospermic patients with respect to semen analysis, it was observed that head, mid-piece and tail defects were comparatively much higher in severe oligozoospermic individuals than mild/moderate individuals (Table II). Similarly, the movement of sperms, either lateral or forward movement was observed much lesser in severe forms of oligozoospermia than mild/ moderate oligozoospermia (Table II). In the same way, the total number of sperms and number of motile sperms were half the number of sperms in moderate oligozoospermia (Table II).

Table II. Semen analysis of oligozoospermic males in low sperm and moderate sperm count individuals.

\begin{tabular}{lll}
\hline Description & $\begin{array}{l}\text { Severe oligo- } \\
\text { zoospermia } \\
(\mathbf{n = 5 0 )}\end{array}$ & $\begin{array}{l}\text { Moderate oli- } \\
\text { gozoospermia } \\
(\mathbf{n = 5 0 )}\end{array}$ \\
\hline Total No. of sperms (million) & $2.0-10$ & $20-48$ \\
Motile sperms (percent) & $20-27$ & $28-55$ \\
No of dead sperms (percent) & $50-63$ & $20-50$ \\
Lateral movement (percent) & $12-20$ & $20-50$ \\
Forward movement (percent) & $10-14$ & $15-27$ \\
Head defects (percent) & $28-68$ & $30-65$ \\
Mid-piece defects (percent) & $30-58$ & $26-55$ \\
Tail defects (percent) & $28-52$ & $25-45$ \\
\hline
\end{tabular}

Characterization of SRY gene

On sequencing the $S R Y$ gene of all oligozoospermia individuals, it was found that like the normal individuals, all the patients had normal sequence of the gene and no point mutation or deletion was found. The sequence of $S R Y$ gene of oligozoospermia individuals can be found in the supplementary data.

\section{DISCUSSION}

Characterization of 120 oligozoospermia patients of D. I. Khan district was done in terms of analysis of both blood and semen samples for detection and quantitative measurements of heavy metals, semen analysis for morphological defects, and sequencing the $S R Y$ gene for any possible mutation. $S R Y$ gene was sequenced because $30 \%$ of the patients had smaller sized testes in their clinical history and that $A Z F$ gene of infertile patients was previously sequenced by the same group of researchers but the results were not promising and only $2 \%$ of the patients (data not shown) had point mutations in the AZFc region only. The total number of sperms in severe oligozoospermic patients were ten times lesser compared to mild oligozoospermic individuals and this had slight deviation from general perception. Similarly, the motility of sperms in severe forms were two times smaller than mild 
oligozoospermic patients. More interestingly, significant difference was found in the number of dead sperms as severe type of oligozoospermia had two times more dead sperms and the movements of alive sperms were also comparatively lesser than mild/moderate forms and this was in disagreement with what was previously described (Mou et al., 2013). In the same way, morphological defects were found much greater in severe oligozoospermia than mild and moderate forms of oligozoospermia. Five heavy metals were detected, either in greater or in less quantities both in blood and semen samples. Interestingly, all the 5 heavy metals were found in comparatively highest quantities in the above 47 years of age group, both in blood and semen samples, possibly the metals had gotten comparatively more time to accumulate in the body. The mean values of all heavy metals in combined form were smallest in 36-41 years of age group. Cadmium is known to be one of the key players in inducing degeneration of male reproductive organs (Monsefi et al., 2010). The metal can lead to decreased concentration of spermatozoa, diminished motility of sperms and causing damages to testes (Laskey et al., 1991). Moreover, Cd with blood concentration of $0.85 \mathrm{mg} / \mathrm{L}$ to $1.31 \mathrm{mg} / \mathrm{L}$ has been shown to have negative association with sperm motility, sperm concentration, semen volume and testis size (Siu et al., 2009a; Xu et al., 1993). The present studies showed that the highest means concentration of $0.098 \mu \mathrm{g} / \mathrm{ml}$ and $0.09 \mu \mathrm{g} / \mathrm{ml}$ were recorded in blood and semen samples respectively of above-47 years of age group. Significant variations were found in the quantitative measurements of the metal were observed among the age groups in blood samples. The observed values were intermediate between the maximum permissible limit $(0.05-2.0 \mu \mathrm{g} / \mathrm{g})$ set by WHO/FAO (FAO, 1983, 1989; WHO, 1989) and can cause serious health problems if not considered properly. The hexavalent chromium is reported be very toxic in causing stomach problems, skin diseases and mutagenic if taken into the body (Wirth and Mijal, 2010; Yousef et al., 2009). In the present study, mean concentrations of $\mathrm{Cr}$ was found comparatively in higher quantities $(0.69 \mu \mathrm{g} / \mathrm{ml})$ in blood samples of age group above- 47 years while the same metal in semen samples was found in its highest amounts $(0.53 \mu \mathrm{g} / \mathrm{ml})$ in $24-29$ years of age group. Due to lack of facilities, identification of various isotopes of $\mathrm{Cr}$ during this study was not possible. Lead in its chloride form can lead to diminished sperm motility (Winder, 1993; Robins et al., 1997). The impact of hazardous effects, even at smaller concentration, on male reproductive organs have been investigated and confirmed (Pizent et al., 2012; Ghaffari and Motlagh, 2011). The permissible limit of $\mathrm{Pb}$ in blood defined by WHO is below $40 \mu \mathrm{g} / \mathrm{ml}$. Reproductive toxicity may occur even below the permissible limit of $\mathrm{Pb}$ (Winder,
1993; Robins et al., 1997). In the present studies, the highest mean concentration of $0.245 \mu \mathrm{g} / \mathrm{ml}$ was observed in above- 47 years that was well well-below the permissible limit set by WHO. Like $\mathrm{Zn}$, the concentrations of $\mathrm{Pb}$ in blood samples were found comparatively higher than semen samples. These observed concentrations in $78 \%$ of cases were exceeding the lower permissible limit (0.05$2.0 \mu \mathrm{g} / \mathrm{g}$ ) set by WHO/FAO (FAO, 1983, 1989; WHO, 1989) which is alarming for general public of the region. Copper is one of the metals required for proper functioning in hematopoietic process and for normal activities of various enzymes (Ardakani et al., 2014; Lavranos et al., 2012). However, it can be lethal if get accumulated in excessive amounts in human body (Ardakani et al., 2014). In the present study, the comparatively higher mean concentration of the metal was found in above 47 years of age group in blood samples and lowest in 42-47 years of age group. These findings were comparatively much smaller than the maximum permissible limit $(30 \mu \mathrm{g} / \mathrm{g})$ according to WHO/FAO (FAO, 1983, 1989; WHO, 1989), but is still alarming and can be detrimental to inhabitants of D. I. Khan. Zinc is one of the vital metals needed for proper cellular metabolic activities (Pizent et al., 2012). However, it can be very toxic when found in excessive quantities (Pizent et al., 2012). The present data showed equal highest mean concentration in 18-23 and above-47 years of age groups, that was quite interesting, probably the patients were taking $\mathrm{Zn}$ in medicine from external source. But these values were comparatively smaller than maximum permissible limit $(30-100 \mu \mathrm{g} / \mathrm{g})$ according to WHO/FAO (FAO, 1983, 1989; WHO, 1989). Interestingly, the concentration in blood samples varied significantly from that of semen samples both in the same individual and among the members of the same age group. Which age group possesses highest quantities of all the 5 detected metals? was also characterized. It was observed that above-47 years of age group contained the highest amount of metals in their blood samples, while $42-47$ years of age group contained the highest quantities of all metals in their semen samples. The smallest quantities were found in the age group 36-41 years. These findings showed that accumulation of heavy metals either need time to be collected and settled in or the age of hoteling and taking food outside the home. Furthermore, the inhabitants of the area take fish extensively as food and it is the main carrier of introducing the above mentioned heavy metals into the bodies of people the region in significant quantities.

\section{CONCLUSION}

Presence of heavy metals in the bodies of oligozoospermia males is one of the main causative agents 
of infertility and that locally available fish of river Indus being used as food component is mainly responsible of introducing these heavy metals into the bodies of inhabitants of D. I. Khan.

\section{Statement of conflict of interest}

The authors have declared no conflict of interest.

Financial support

Self-supported

\section{REFERENCES}

Abdulali, T., Shuhaimi-Othman, M. and Ahmad, A.K., 2003. Assessment of heavy metals in tilapia fish (Oreochromis niloticus) from the Langat river and engineering lake in Bangi, Malaysia and evaluation of the health risk from tilapia consumption. Ecotoxilcol. environ. Safe., 93: 45-51. https://doi. org/10.1016/j.ecoenv.2013.03.031

Adachi, T., Yasutake, A. and Hirayama, K., 1992. Influence of dietary protein levels on the fate of methylmercury and glutathione metabolism in mice. Toxicology, 72: 17-26. https://doi. org/10.1016/0300-483X(92)90082-P

Apostoli, P. and Catalani, S., 2011. Metal ions affecting reproduction and development. Met. Ions. LifeSci., 8: 263-303. https://doi.org/10.1039/978184973211600263

Ardakani, S.S. and Jafari, S.M., 2014. Assessment of heavy metals $(\mathrm{Cu}, \mathrm{Pb}$ and $\mathrm{Zn})$ in different tissues of common carp (Cyprinus carpio) caught from Shirinsu Wetland, Western Iran. J. Chem. Hlth. Risks, 4: 47-54.

Benoff, S., Jacob, A. and Hurley, I.R., 2000. Male infertility and environmental exposure to lead and cadmium. Hum. Reprod. Update, 6: 107-121. https://doi.org/10.1093/humupd/6.2.107

CDC, 2003. Second national report on human exposure to environmental chemicals. Centers for Disease Control And Prevention, National Center for Environmental Health, Division of Laboratory Sciences, Atlanta, USA 2003.

CDC, 2005. Third national report on human exposure to environmental chemicals. Centers for disease control and prevention, national center for environmental health, division of laboratory sciences, Atlanta, USA 2005.

Dale, B., Iaccarino, M., Fortunato, A., Gragnaniello, G., Kyozuka, K. and Tosti, E., 1994. A morphological and functional study of fusibility in roundheaded spermatozoa in the human. Fertil. Steril.,
61: 336-340. https://doi.org/10.1016/S00150282(16)56528-5

Falender, A.E., Freiman, R.N., Geles, K.G., Lo, K.C., Hwang, K., Lamb, D.J., Morris, P.L., Tjian, R. and Richards, J.S., 2000. Maintenance of spermatogenesis requires TAF4b, a gonad-specific subunit of TFIID. Genes Dev., 19: 794-703. https:// doi.org/10.1101/gad.1290105

Food and Agricultural Organization, 1983. Compilation of legal limits for hazardous substance in fish and fishery products. Food and Agricultural Organization, Rome. Fishery circular, No 464., pp. 5-100.

Food and Agricultural Organization/World Health Organization, 1989. Evaluation of certain food additives and the contaminants mercury, lead and cadmium. World Health Organization, Geneva. Technical Report Series No. 505.

Freiman, R.N., Albright, S.R., Zheng, S., Sha, W.C., Hammer, R.E. and Tjian, R., 2001. Requirement of tissue-selective TBP-associated factor TAFII105 in ovarian development. Science, 293: 2084-2087. https://doi.org/10.1126/science.1061935

Ghaffari, M.A. and Motlagh, B., 2011. In vitro effect of lead, silver, tin, mercury, indium and bismuth on human sperm creatine kinase activity: A presumable mechanism for men infertility. Iran. biomed. J., 15: 38-43.

Karaca, N., Yilmaz, R., Kanten, G.E., Kervancioglu, E., Solakoglu, S. and Kervancioglu, M.E., 2014. First successful pregnancy in a globozoospermic patient having homozygous mutation in SPATA16. Fertil. Steril., 102: 103-107. https://doi.org/10.1016/j. fertnstert.2014.04.002

Kuo, Y.C., Lin, Y.H., Chen, H.I., Wang, Y.Y., Chiou, Y.W., Lin, H.H., Pan, H.A., Wu, C.M., Su, S.M., Hsu, C.C. and Kuo, P.L., 2012. SEPT12 mutations cause male infertility with defective sperm annulus. Hum. Mutat. 33: 710-719. https://doi.org/10.1002/ humu. 22028

Laskey, J.W. and Phelps, P.V., 1991. Effect of cadmium and other metal cations on in vitro Leydig cell testosterone production. Toxicol. appl. Pharmacol., 108: 296-306. https://doi.org/10.1016/0041008X(91)90119-Y

Lavranos, G., Balla, M., Tzortzopoulou, A., Syriou, V. and Angelopoulou, R., 2012. Investigating ROS sources in male infertility: A common end for numerous pathways. Reprod. Toxicol., 34: 298-307. https://doi.org/10.1016/j.reprotox.2012.06.007

Miller, S.A., Dykes, D.D. and Polesky, H.F., 1988. A simple salting out procedure for extracting DNA 
from human nucleated cells. Nucl. Acids Res. 16: 1215. https://doi.org/10.1093/nar/16.3.1215

Monsefi, M., Alaee, S., Moradshahi, A. and Rohani, L., 2010. Cadmium induced infertility in male mice. Environ. Toxicol., 25: 94-102. https://doi. org/10.1002/tox.20468

Mosher, W.D., 1985. Reproductive impairments in the United States. Demography, 22: 415-430. https:// doi.org/10.2307/2061069

Mou, L., Wang, Y., Li, H., Huang, Y., Jiang, T., Huang, W., Li, Z., Chen, J., Xie, J., Liu, Y., Jiang, Z., Li, X., Ye, J., Cai, Z. and Gui, Y., 2013. A dominantnegative mutation of HSF2 associated with idiopathic azoospermia. Hum. Genet., 132: 159165. https://doi.org/10.1007/s00439-012-1234-7

Nordberg, G.F., Fowler, B.A., Nordberg, M. and Friberg, L., 2007. Handbook on the toxicology of metals. $3^{\text {rd }}$ ed. Academics, Oxford. pp. 117-145. https://doi. org/10.1016/B978-012369413-3/50062-8

Pizent, A., Tariba, B., Živković, T., 2012. Reproductive toxicity of metals in men. Arh. Hig. Rada. Toksikol., 63 (Suppl-1): 35-46. https://doi. org/10.2478/10004-1254-63-2012-2151

Robins, T.G., Bornman, M.S., Ehrlich, R.I., Cantrell, A.C., Pienaar, E., Vallabh, J. and Miller, S., 1997. Semen quality and fertility of men employed in a South African lead acid battery plant. Am. J. Indust. Med., 32: 369-375. https://doi.org/10.1002/ (SICI) 1097-0274(199710)32:4<369::AIDAJIM8>3.0.CO;2-P

Sanger, F., Nicklen, S. and Coulson, A.R., 1977. DNA sequencing with chain terminating inhibitors.
Proc. natl. Acad. Sci., 74: 5463-5467. https://doi. org/10.1073/pnas.74.12.5463

Siu, E.R., Mruk, D.D., Porto, C.S. and Cheng, C.Y., 2009a. Cadmium induced testicular injury. Toxicol. appl. Pharmacol. 238: 240-249. https://doi. org/10.1016/j.taap.2009.01.028

Symposium Proceedings, 1992. Cadmium in the human environment: toxicity and carcinogenicity. Gargnano, Italy. IARC Sci. Publ., 118: 1-464.

Wang, S., Zheng, H., Esaki, Y., Kelly, F., Yan, W., 2006. Cullin-3 is a KLHL10- interacting protein preferentially expressed during late spermiogenesis. Biol. Reprod., 74: 102-108. https://doi.org/10.1095/ biolreprod.105.045484

WHO, 1989. Heavy metals-environmental aspects: Environment health criteria. No. 85. Geneva, Switzerland.

Winder, C., 1993. Lead, reproduction and development. Neurotoxicology, 14: 303-318.

Wirth, J.J. and Mijal, R.S., 2010. Adverse effects of low level heavy metal exposure on male reproductive function. Syst. Biol. Reprod. Med., 56: 147-167. https://doi.org/10.3109/19396360903582216

Xu, B., Chia, S.E., Tsakok, M., and Ong, C.N., 1993. Trace elements in blood and seminal plasma and their relationship to sperm quality. Reprod. Toxicol., 7: 613-618. https://doi.org/10.1016/08906238(93)90038-9

Yousef, M.I. and Salama, A.F., 2009. Propolis protection from reproductive toxicity caused by aluminium chloride in male rats. Fd. Chem. Toxicol., 47: 11681175. https://doi.org/10.1016/j.fct.2009.02.006 